Research Paper

\title{
HtrA3 Is Downregulated in Cancer Cell Lines and Significantly Reduced in Primary Serous and Granulosa Cell Ovarian Tumors
}

\author{
Harmeet Singh, Ying Li, Peter J Fuller, Craig Harrison, Jyothsna Rao, Andrew N Stephens and Guiying \\ $\mathrm{Nie}^{\otimes}$ \\ Prince Henry's Institute of Medical Research, Clayton, Victoria 3168, Australia.
}

$\triangle$ Corresponding author: Harmeet Singh, Prince Henry's Institute of Medical Research, PO Box 5152, 246 Clayton Road, Clayton, VIC 3168, Australia. Fax: +61 39594 6125; email: harmeet.singh@princehenrys.org.

( ) Ivyspring International Publisher. This is an open-access article distributed under the terms of the Creative Commons License (http://creativecommons.org/ licenses/by-nc-nd/3.0/). Reproduction is permitted for personal, noncommercial use, provided that the article is in whole, unmodified, and properly cited.

Received: 2012.12.13; Accepted: 2013.01.10; Published: 2013.02.01

\begin{abstract}
Objective. The high temperature requirement factor $\mathrm{A} 3(\mathrm{Htr} \mathrm{A} 3)$ is a serine protease homologous to bacterial HtrA. Four human HtrAs have been identified. HtrAl and HtrA3 share a high degree of domain organization and are downregulated in a number of cancers, suggesting a widespread loss of these proteases in cancer. This study examined how extensively the HtrA (HtrAl-3) proteins are downregulated in commonly used cancer cell lines and primary ovarian tumors.

Methods. RT-PCR was applied to various cancer cell lines $(n=17)$ derived from the ovary, endometrium, testes, breast, prostate, and colon, and different subtypes of primary ovarian tumors [granulosa cell tumors $(n=19)$, mucinous cystadenocarcinomas $(n=6)$, serous cystadenocarcinomas $(n=8)]$ and normal ovary $(n=9)$. HtrA3 protein was localized by immunohistochemistry.

Results. HtrA3 was extensively downregulated in the cancer cell lines examined including the granulosa cell tumor-derived cell lines. In primary ovarian tumors, the HtrA3 was significantly lower in serous cystadenocarcinoma and granulosa cell tumors. In contrast, HtrAl and HtrA2 were expressed in all samples with no significant differences between the control and tumors. In normal postmenopausal ovary, $\mathrm{HtrA} 3$ protein was localized to lutenizing stromal cells and corpus albicans. In serous cystadenocarcinoma, HtrA3 protein was absent in the papillae but detected in the mesenchymal cyst wall.

Conclusion. HtrA3 is more extensively downregulated than $\mathrm{HtrAl}-2$ in cancer cell lines. HtrA3, but not HtrAl or HtrA2, was decreased in primary ovarian serous cystadenocarcinoma and granulosa cell tumors. This study provides evidence that $\mathrm{HtrA} 3$ may be the most relevant $\mathrm{HtrA}$ associated with ovarian malignancy.
\end{abstract}

Key words: HtrA3, ovarian cancer, protease, GCT, Serous cystadenocarcinoma.

\section{Introduction}

Ovarian cancer undergoes progressive "dedifferentiation" from a well to a poorly differentiated tumor, then spreads to the pelvic and abdominal cavities before metastasizing to distant sites. It represents one of the most aggressive and heterogeneous cancer types in women and is a leading cause of gynaecological deaths $[1,2]$. The majority of ovarian cancer patients are diagnosed at late stages when conven- 
tional therapy is less effective, leading to high levels of morbidity and mortality [3]. It has therefore been proposed that survival for this highly lethal disease could be improved by developing screening methods that detect the disease when it is confined to the ovary. A number of biomarkers have been investigated which are involved in the development and progression of ovarian cancer [4]. Despite initial responses to surgery and chemotherapy, most of the affected women ultimately die from recurrence and development of chemoresistance [5]. These highlight the need for identifying new prognostic markers to better determine patients with more aggressive disease, appropriate for treatment.

The high temperature requirement (HtrA) family of serine proteases are well conserved from bacteria to humans. Bacterial HtrA is the most studied member of this family and is necessary for bacterial survival at elevated temperatures [6]. It acts as a chaperone at normal temperature and protease at elevated temperatures [7, 8]. To date, four human HtrAs have been identified: HtrA1 [9, 10], HtrA2 [11, 12], HtrA3 [13, 14] and HtrA4 [15, 16]. All HtrA proteins share a highly conserved serine protease domain and one PDZ domain at the C-terminus [17]. They appear to be involved in inflammation, apoptosis, ische$\mathrm{mia} /$ reperfusion, neurodegenerative conditions and neuromuscular disorders, and protection against stress conditions including heat shock [reviewed in [18]].

HtrA proteins, especially HtrA1 and HtrA3, are reported to be downregulated in a number of cancers [19-21]. Both HtrA1 and HtrA3 have been implicated as inhibitors of invasion and tumor suppression [22-24]. HtrA1 is downregulated in SV40 transformed fibroblasts $[9,10]$. Several reports have indicated a tumor suppressive role for HtrA1 in breast, lymph node melanoma, ovarian and gastric cancers [21, 25-27].

HtrA2 is a stress-activated protease that is up-regulated in mammalian cells in response to cellular stress [12]. It is involved in apoptosis [28-30], a process which is impaired in cancer progression, and thus might play a role in malignancy.

HtrA3 was initially identified as a pregnancy-related serine protease [31]. Two variants of HtrA3 that arise from alternative mRNA splicing [long (HtrA3-L) and short (HtrA3-S)] have been identified [13]. HtrA3-S is identical to the long form except it lacks the terminal PDZ domain [13]. The HtrA3 isoforms may recognize different substrates and thus may have different functions. HtrA3 shares a high degree of sequence and domain organization with HtrA1 [10, 13], suggesting similar functions. HtrA3
mRNA levels are reported to be downregulated with increasing grades of human endometrial, ovarian and lung cancer [20,32,33]. The role of HtrA4, a newly identified member of the mammalian HtrA family, in cancer progression has not been reported.

The aims of the present study were to evaluate and compare the extent of the downregulation of HtrA1, HtrA2, and HtrA3 (HtrA3-L and HtrA3-S) mRNA levels in a number of commonly used human cancer cell lines and different sub-types of primary ovarian tumor tissues [serous, mucinous and granulosa cell tumor (GCT)]. We further used immunohistochemistry to investigate HtrA3 protein localization in primary ovarian cancers.

\section{Materials and Methods}

\section{Cell Lines and total RNA}

Human granulosa cell tumor-derived cancer cells KGN and COV434, endometrial ECC1, HEC-1A, HEC-1B, Ishikawa, RL95-2 and AN3CA, testicular Ntera-2D, breast MCF-7 and MDA-231, prostate PC3, DU145 and LNCap, and colon SW480 and WIDR cell lines were cultured in medium supplemented with $10 \%$ fetal calf serum (SAFC Biosciences, KS), $2 \mathrm{mM}$ L-glutamine, $100 \mu \mathrm{g} / \mathrm{ml}$ streptomycin $/ 100 \mathrm{IU} / \mathrm{ml}$ penicillin (both from Gibco, Carlsbad, CA). All cell lines were cultured in DMEM, except for HEC-1A in McCoy's, and RL95-2 cells in DMEM supplemented with $10 \mu \mathrm{g} / \mathrm{ml}$ bovine insulin (Actrapid, Novo Nordisk, Denmark). RNA was isolated using RNeasy Minikit (Qiagen $\mathrm{GmbH}$, Hilden, Germany) and ribonuclease-free deoxyribonuclease-1 (DNA-free kit, Ambion, TX). Total RNA from human breast, prostate and testes was from Ambion (Life Technologies). Approval was obtained from the Human Research Ethics Committee at Monash Medical Centre, Melbourne to isolate total RNA from ovarian, colon and endometrial tissues.

\section{Isolation of RNA from tissue specimens}

Ovarian tumour tissues [granulosa cell tumors $(n=19)$, mucinous cystadenocarcinomas $(n=6)$ and serous cystadenocarcinomas $(n=8)]$ were obtained from banked tissue samples which had previously been used in different studies [34-36]. Normal ovarian tissues were obtained from nine premenopausal women who had undergone elective hysterectomy with oophorectomy for a range of conditions not associated with ovarian malignancy. Details of individual patients are provided in Table 1 . The tissues were snap-frozen and then stored at $-80{ }^{\circ} \mathrm{C}$ prior to RNA extraction. The Human Research and Ethics 
Committee of Monash Medical Centre approved this study protocol.

Total RNA was extracted from tissues using guanidinium thiocyanate-cesium chloride as previously described [37]. All RNA samples were
DNaseI-treated as per manufacturer's instructions (DNA-free kit; Ambion, Texas, USA). RNA concentration was determined at 260nm using an ND1000 Nanodrop spectrophotometer (Thermo Scientific, Wilmington, DE, USA).

Table I. Individual patient characteristics.

\begin{tabular}{|c|c|c|c|c|}
\hline Sample number & Sample Type & Patient Age & Menopausal Status & Stage \\
\hline S1 & Serous & 56 & $\mathrm{~N} / \mathrm{A}$ & Unstaged \\
\hline S2 & Serous & 71 & Post & $3 C$ \\
\hline S3 & Serous & 71 & Post & $3 C$ \\
\hline S4 & Serous & 75 & Post & $3 C$ \\
\hline S6 & Serous & 68 & Post & $3 C$ \\
\hline S7 & Serous & 83 & Post & $3 C$ \\
\hline S8 & Serous & 51 & Post & $3 C$ \\
\hline S9 & Serous & 72 & Post & $3 C$ \\
\hline M2 & Mucinous & 87 & Post & Unstaged \\
\hline M5 & Mucinous & 65 & Post & 1 \\
\hline M9 & Mucinous & 84 & Post & 1 \\
\hline M10 & Mucinous & 64 & Post & 2 \\
\hline M12 & Mucinous & $\mathrm{N} / \mathrm{A}$ & $\mathrm{N} / \mathrm{A}$ & $\mathrm{N} / \mathrm{A}$ \\
\hline M13 & Mucinous & $\mathrm{N} / \mathrm{A}$ & $\mathrm{N} / \mathrm{A}$ & $\mathrm{N} / \mathrm{A}$ \\
\hline N7 & Normal & 49 & Pre & Fibroid uterus \\
\hline N8 & Normal & 33 & Pre & Intractable premenstrual tension \\
\hline N9 & Normal & 30 & Pre & Endometrial carcinoma \\
\hline N10 & Normal & 50 & Pre & Endometrial carcinoma \\
\hline N11 & Normal & 48 & Pre & endometriosis/adenomyosis \\
\hline N13 & Normal & 48 & Pre & $\mathrm{N} / \mathrm{A}$ \\
\hline 818 & Normal & $\mathrm{N} / \mathrm{A}$ & $\mathrm{N} / \mathrm{A}$ & $\mathrm{N} / \mathrm{A}$ \\
\hline 884 & Normal & $\mathrm{N} / \mathrm{A}$ & $\mathrm{N} / \mathrm{A}$ & $\mathrm{N} / \mathrm{A}$ \\
\hline 927 & Normal & $\mathrm{N} / \mathrm{A}$ & $\mathrm{N} / \mathrm{A}$ & $\mathrm{N} / \mathrm{A}$ \\
\hline G5 & GCT & 31 & Pre & 1 \\
\hline G6 & GCT & 48 & Pre & Recurrent, metaststic \\
\hline G7 & GCT & 43 & Pre & $1 \mathrm{~A}$ \\
\hline G9 & GCT & 85 & Post & Recurrent, metaststic \\
\hline G10 & GCT & $\mathrm{N} / \mathrm{A}$ & $\mathrm{N} / \mathrm{A}$ & N/A \\
\hline G11 & GCT & 66 & Post & Recurrent, metaststic \\
\hline G12 & GCT & 58 & Post & Recurrent, metaststic \\
\hline G13 & GCT & 17 & Pre & Juvenile, recurrent (metastatic) \\
\hline G14 & GCT & 50 & Pre & Recurrent \\
\hline G15 & GCT & 33 & Pre & Juvenile, recurrent \\
\hline G17 & GCT & 53 & Pre & 1 \\
\hline G18 & GCT & 54 & Pre & 1 \\
\hline G19 & GCT & 45 & Pre & Recurrent \\
\hline G20 & GCT & 71 & Post & Recurrent \\
\hline G22 & GCT & 4 & Pre & Juvenile \\
\hline G23 (137) & GCT & 81 & Post & High Grade \\
\hline G24 (1342) & GCT & 50 & Post & 1c \\
\hline G26 & GCT & 54 & Post & 1 \\
\hline G27 & GCT & 79 & Post & 1 \\
\hline
\end{tabular}

Pre: pre-menopausal; Post: post-menopausal; N/A: Not available. Samples from patients numbered - S1-S9 $(n=8)$ are serous; M2-M13 $(n=6)$ are mucinous; G5-G27 $(\mathrm{n}=19)$ are from Granulosa cell tumor $(\mathrm{GCT})$; N7-N13, 818, 884 and $927(\mathrm{n}=9)$ are normal. 
Table 2. The primer sequences and reaction conditions for RT-PCR.

\begin{tabular}{|c|c|c|c|}
\hline Gene & $\begin{array}{l}\text { Primer Sequences }\left(5^{\prime}-3^{\prime}\right) \\
\text { F- Forward, R- Reverse }\end{array}$ & $\begin{array}{l}\text { Annealing temperature }\left({ }^{\circ} \mathrm{C}\right) \text { and cycles } \\
(\mathrm{n}) \text { - Block PCR }\end{array}$ & PCR Product size (bp) \\
\hline HTRA1 & $\begin{array}{l}\text { F - AAA GCC ATC ACC AAG AAG AAG TAT } \\
\text { R - TCC TCA TCC GTC ATC CAC }\end{array}$ & 58 (30 cycles) & 384 \\
\hline HTRA2 & $\begin{array}{l}\text { F - GCC GTG GTC TAT ATC GAG ATC CT } \\
\text { R - TGC CGG ATG TGA TCG TGT }\end{array}$ & 58 (30 cycles) & 343 \\
\hline HTRA3-L (Long) & $\begin{array}{l}\text { F - ATG CGG ACG ATC ACA CCA AG } \\
\text { R - CGC TGC CCT CCG TTG TCT G }\end{array}$ & 58 (30 cycles) & 337 \\
\hline HTRA3-S (short) & $\begin{array}{l}\text { F - GAG GGC TGG TCA CAT GAA GA } \\
\text { R - GCT CCG CTA ATT TCC AGT }\end{array}$ & 53 (35 cycles) & 320 \\
\hline $18 \mathrm{~S}$ & $\begin{array}{l}\text { F - CGG CTA CCA CAT CCA AGG AA } \\
\text { R - GCT GGA ATT ACC GCG GCT }\end{array}$ & 64 (26 cycles) & 187 \\
\hline
\end{tabular}

\section{Reverse transcription polymerase chain reac- tion (RT-PCR) analysis}

Total RNA $(1 \mu \mathrm{g})$ was reverse transcribed using AMV reverse transcriptase (Roche, Mannheim, Germany) as previously reported [24]. The cDNA product $(1 \mu \mathrm{l})$ was amplified using GoTag green master mix (Promega, Hawthorn, VIC, Australia) and $10 \mathrm{pmol}$ of forward and reverse primers for HtrA1, HtrA2 and HtrA3 [long (L) and short (S) isoforms] and 18S (Table 2). All PCRs were run in duplicate and products were analysed by electrophoresis on $1 \%$ agarose gel (Roche), stained with Gel Red (Biotium, Stepney, SA, Australia) and imaged with Gel Doc-2000 (Bio-Rad, Hercules, CA). A non template control in which diethyl pyrocarbonate water was substituted for RT was included as a negative control. As a loading control, $18 \mathrm{~S}$ was amplified for each RT reaction.

\section{Immunohistochemistry}

Normal ovarian tissues and serous epithelial ovarian cancer tissues from post-menopausal women were collected prospectively from women undergoing surgery for suspected gynaecological malignancies. All samples were collected from anaesthetised patients who had no prior treatment for their malignancies, and had no other history of malignant disease. Tissue samples were collected with prior approval from the Southern Health Human Research Ethics Committee and with prior informed written consent from participants. The tissues were formalin fixed and embedded in paraffin.

Sections of $5 \mu \mathrm{m}$ thickness on Superfrost plus slides were subjected to standard immunohistochemistry. After de-paraffinization and rehydration, antigen was retrieved by microwaving $[5 \mathrm{~min} 700 \mathrm{~W}$ in $0.01 \mathrm{~mol} / \mathrm{L}$ sodium citrate buffer $(\mathrm{pH} 6.0)]$, endogenous peroxidase was quenched with $3 \%$ hydrogen peroxide in methanol for $10 \mathrm{~min}$, and the non-specific binding was blocked with pre-immune blocking serum $[15 \%$ normal rabbit serum plus $2 \%$ normal human serum in high salt Tris buffered saline (HS-TBS) with $0.1 \%$ Tween-20] for $40 \mathrm{~min}$ at room-temperature. The primary antibody [custom-made sheep anti-HtrA3 antibody [14]] or preimmune sheep $\operatorname{IgG}$ as a negative control (both $0.5 \mu \mathrm{g} / \mathrm{ml}$ ) was diluted in the blocking buffer ( $10 \%$ fetal calf serum in HB-TBS with $0.1 \%$ Tween-20) and sections were incubated at $37{ }^{\circ} \mathrm{C}$ for $1 \mathrm{~h}$ and washed with high-salt TBS plus $0.6 \%$ Tween. The secondary antibody (biotinylated rabbit anti-sheep IgG, 1:200; Vector Laboratories, Burlingame, CA) was applied in the blocking buffer for $30 \mathrm{~min}$ at room-temperature. Positive immunostaining was revealed by incubating the sections with an avidin-biotin-complex conjugated to horseradish peroxidase (1:100, Vectorstain elite ABC kit) for $30 \mathrm{~min}$ at room-temperature, followed by the application of the peroxidase substrate $3,3 \mathrm{~N}$-diaminobenzidine (DAB, DakoCytomation) leading to a brown precipitate for positive staining. Sections were counterstained with hematoxylin and examined with Olympus $\mathrm{BH} 2 \mathrm{mi}-$ croscope fitted with a Fujix HC-2000 high-resolution digital camera (Fujix, Tokyo, Japan). Sections from normal ovarian tissue were used as positive controls.

\section{Densitometric and statistical analysis}

Densitomety was performed using ImageJ software (Version 1.6, National Institutes of Health, Bethesda, MD). Selected bands were quantified based on their relative intensities. Fold change was calculated relative to $18 \mathrm{~S}$ for each sample. Statistical analysis was performed using Prism for Windows (GraphPad 5.0 Software, San Diego, CA) using a non-parametric Kruskal-Wallis test, followed by Dunns post test. P $<0.05$ was considered significant for data acquired in arbitrary density units. 


\section{Results}

HtrA3 is more extensively and drastically downregulated than HtrAl or HtrA2 in commonly used cancer cell lines.

Expression of HtrA1, HtrA2 and HtrA3 (HtrA3-L and HtrA3-S) in several well characterized cell lines derived from ovary, endometrium, testes, breast, prostrate, and colon was determined by conventional RT-PCR (Fig. 1A \& B). Specific bands of expected size for each candidate gene were detected.

HtrA1 was consistently expressed in all control samples and in ovarian $(n=2)$, endometrial $(n=7)$, testicular $(n=1)$ and prostate $(n=3)$ cancer cell lines screened. It was downregulated in only one of the two breast and colon cancer cell lines examined (Fig. 1B).

Similarly, HtrA2 was also consistently expressed in most of the cancer cell lines screened. All endometrial $(n=7)$, prostate $(n=3)$ and colon $(n=2)$ cancer cell lines and controls were positive for HtrA2 (Fig. 1A \& B). Weak HtrA2 signal was observed in control ovary and in both GCT-derived cancer cell lines, and in control testes and the testicular cancer cell line. Very low levels of HtrA2 were detected in breast control and in both breast cancer cell lines (Fig. 1A \& B).

In contrast, both HtrA3-L and HtrA3-S were downregulated in most of the cancer cell lines examined. In all control samples, positive HtrA3 expression was detected. HtrA3 expression was not detected in either GCT-derived cancer cell lines. Its expression was downregulated in five of the seven endometrial cancer cell lines, in both breast cancer cell lines, in two of the three prostate cancer cell lines, and one of the two colon cancer cell lines (Fig. 1A \& B). However, positive HtrA3 mRNA was detected in the normal testis and testicular cancer cell lines (Fig. 1A \& B).

\section{HtrA3-L mRNA levels are significantly de- creased in primary serous and granulosa ovarian tumors}

We next determined the mRNA levels of HtrA1, HtrA2 and HtrA3 isoforms (HtrA3-L and HtrA3-S) in ovarian tissue samples. Different sub-types of ovarian tumor [serous tumors $(n=8)$, mucinous tumors $(n=6)$, granulosa cell tumors (GCT, $\mathrm{n}=19)]$ were compared to normal premenopausal ovarian tissue $(n=9)$.

HtrA1 mRNA was clearly detected in all ovarian control and tumor samples (Fig. 2A). Densitometric analysis showed no significant differences between control and any ovarian tumor groups (Fig. 2B).
HtrA1 mRNA was lower in serous tumors, but not significantly different from any other groups. HtrA1 expression was more variable across the GCT samples.

HtrA2 was also detected in all ovarian control and tumor samples screened with no significant differences between the groups (Fig. 3A \& B).

Both HtrA3 isoforms (HtrA3-L and HtrA3-S) were expressed in normal and tumor samples (Fig. 4A). However, densitometric analysis corrected for $18 \mathrm{~S}$ showed that the two isoforms were differentially expressed. Compared to the normal tissues, the mean level of HtrA3-L was significantly reduced in the serous tumors and GCT (Fig. 4B). HtrA3-L mRNA levels were variable in mucinous tumors and the mean level was not significantly different from the control.

In contrast, compared to the normal tissues, although the mean levels of HtrA3-S mRNA were also low in serous tumors (Fig. 4C), the levels were not significantly different from the control. No significant changes in HtrA3-S expression were observed in any cancer groups.

\section{HtrA3 protein levels were decreased progres- sively in serous ovarian tumors}

Since HtrA3-L mRNA was significantly downregulated in serous ovarian tumors, we next determined the HtrA3 cellular localisation in the post-menopausal ovarian control and late stage serous carcinoma by immunohistochemistry.

The post-menopausal ovary was dominated by a stroma composed of spindle shaped cells surrounded by abundant collagen bundles and blood vessels. In the post-menopausal ovary, ovarian follicles and the accompanying granulosa cell compartment are lost, as expected. In the control, moderate levels of HtrA3 (Fig. 5A \& B) were detected predominantly in the stroma, particularly in the remaining luteinizing stromal cells and corpus albicans (Fig. 5B).

In the serous carcinoma tumors (grade-3, stages 2-4 - late cancer), papillae are lined by stratified cells of serous type with extensive cellular growth, cellular budding, and increased stromal invasion. In the papillae of the cancer, $\mathrm{HtrA} 3$ was significantly reduced or completely absent (Fig. 5C-F). On sections containing mesenchymal cyst wall and papillae (Fig. 5C \& D), HtrA3 was detected in the mesenchymal cyst wall, but the papillae showed low HtrA3 staining. On sections containing no mesenchymal cyst wall (Fig. 5E $\& \mathrm{~F})$, the papillae was almost negative for HtrA3. 
A
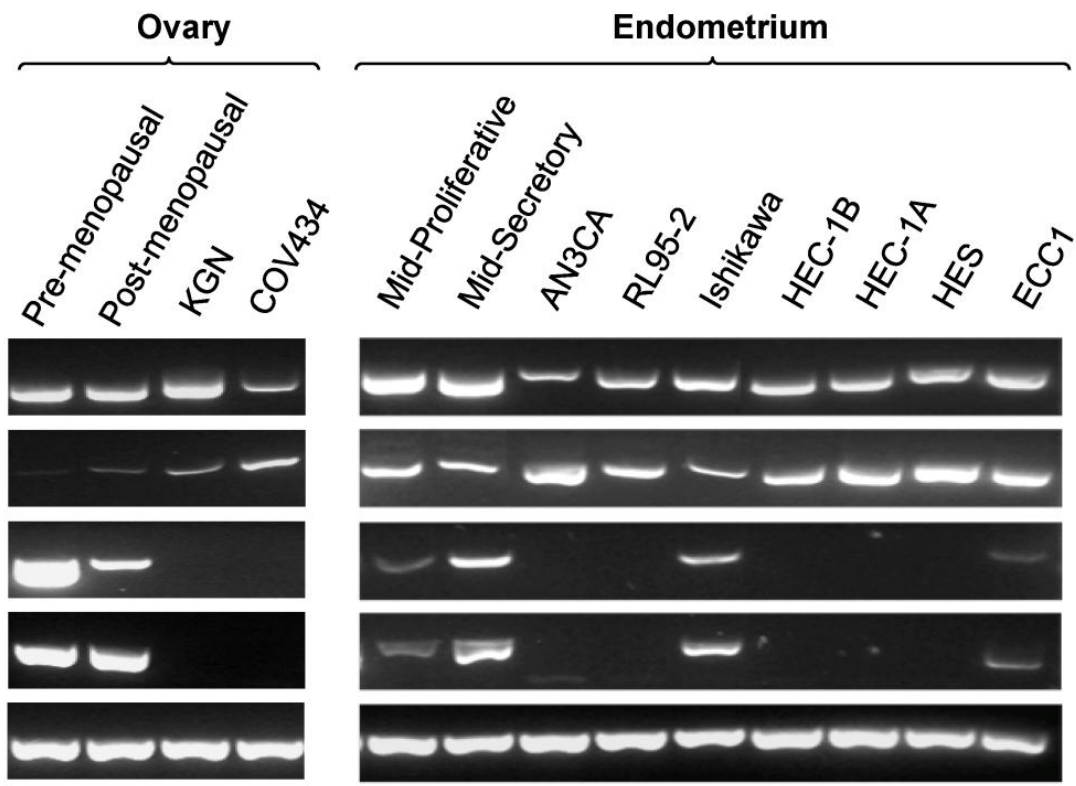

HTRA1

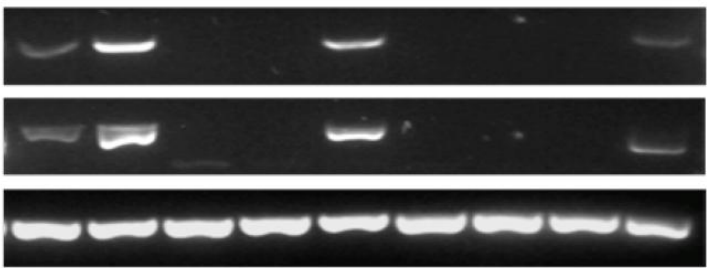

HTRA2

HTRA3 - L

HTRA3 - S

$18 S$

B

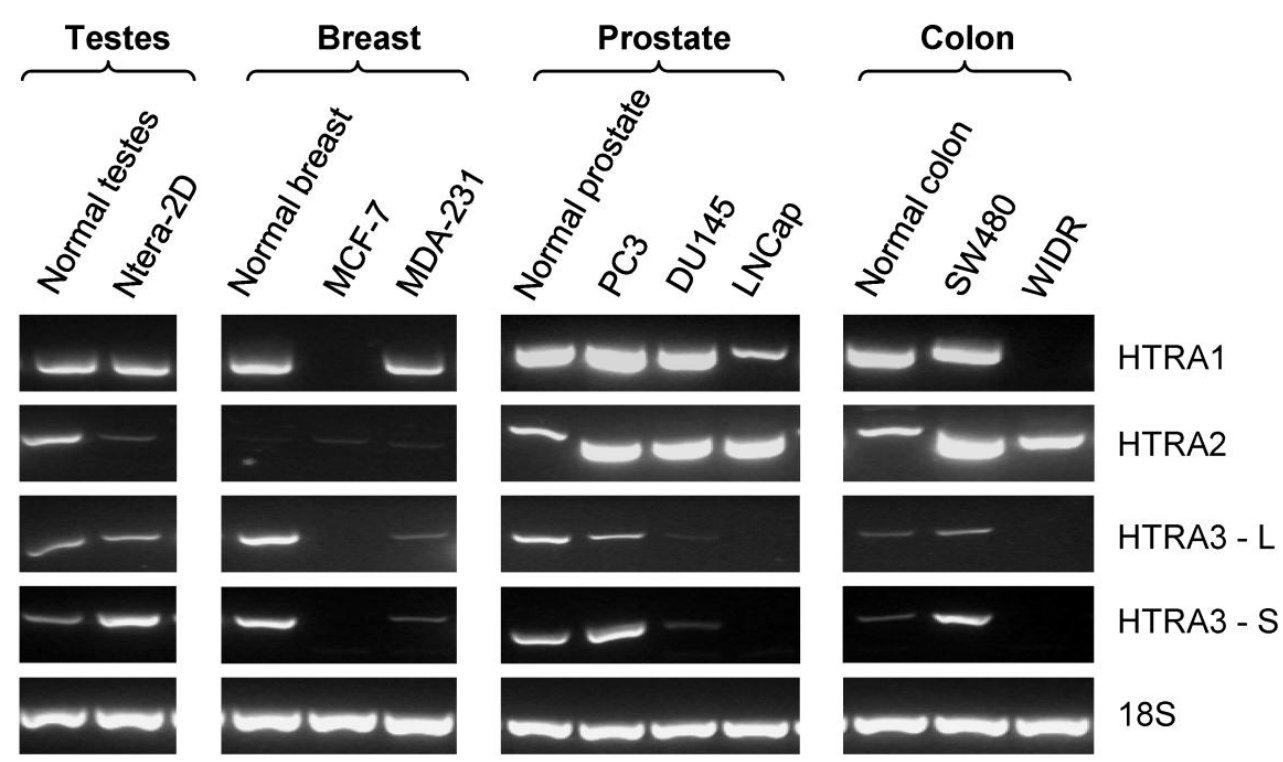

Figure I. RT-PCR analysis of the mRNA levels of human HtrAl, HtrA2 and HrA3 [long (HtrA3-L) and short (HtrA3-S)] in various cancer cell lines. (A) Representative semi-quantitative PCR results from testes, breast, prostate, and colon control and cancer cell lines. (B) Representative semi-quantitative PCR results from ovarian and endometrial control and cancer cell lines. I8S amplification was used as loading control. Pre-menopausal and post-menopausal ovary - normal controls for ovary; Mid-Proliferative and Mid-Secretory - normal controls for mid proliferative and secretory phase endometrium respectively. Cancer cell lines examined, testes - Ntera-2D; breast - MCK-7, MDA-23I; prostate - PC3, DUI45, and LNCap; colon - SW480 and WIDR; ovary - KGN and COV434; endometrium - ECCI, HECI-A, HECI-B, Ishikawa, RL95-2 and AN3CA. 
A

Normal

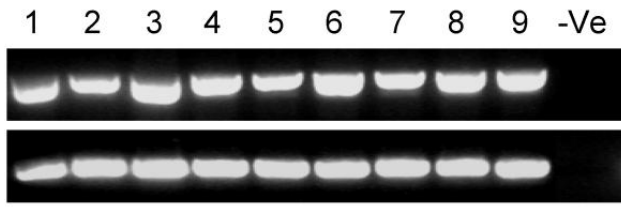

HtrA1

Ovary

$18 \mathrm{~S}$

Serous

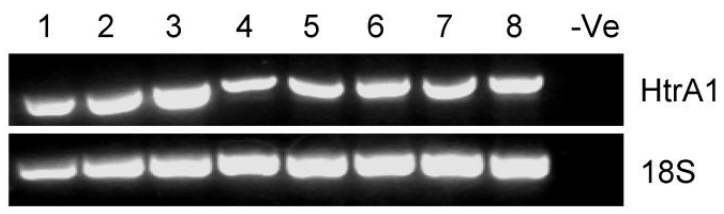

Cancer

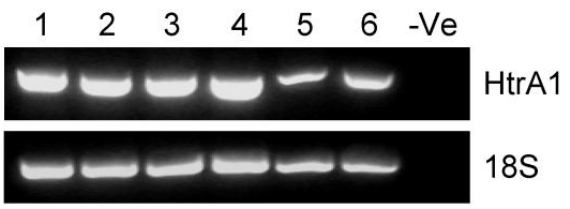

Cancer

GCT

SDS

HtrA1

Cancer

B

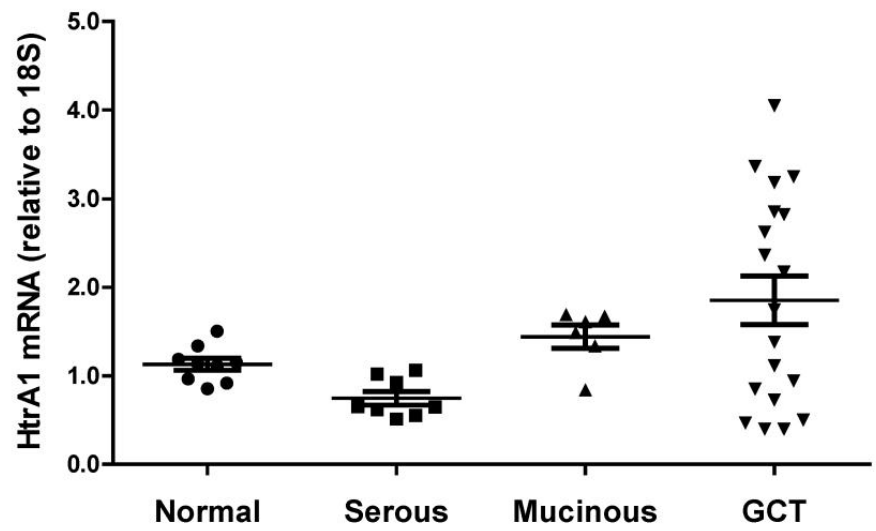

Figure 2. RT-PCR analysis of human HtrAl expression in normal ovary and different types of ovarian tumors. (A) Representative semi-quantitative RT-PCR results from normal ovary and serous, mucinous and granulosa cell tumor (GCT) ovarian cancers. (B) Densitometric analysis showing the relative mRNA levels (corrected for I8S) in normal ovary and ovarian cancer samples. Patient details for normal and cancer groups are summarised in table $\mathrm{I}$. 
A

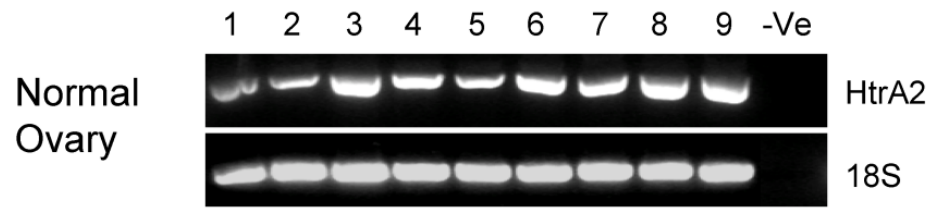

Serous

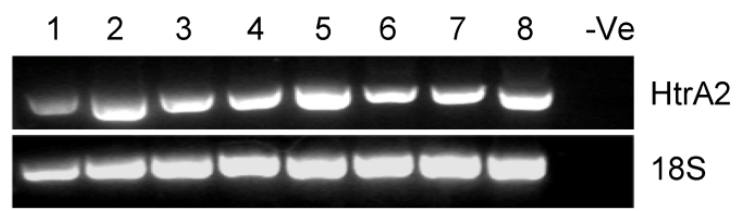

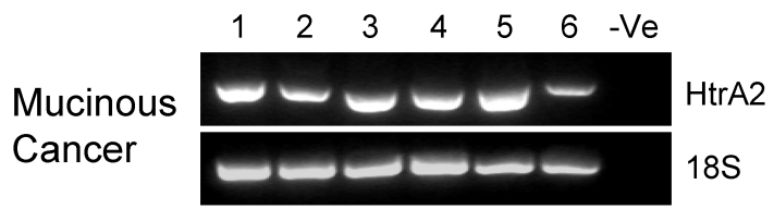

GCT

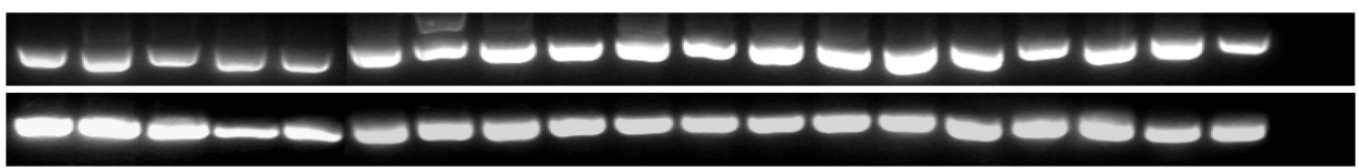

$\mathrm{HtrA} 2$

Cancer

B

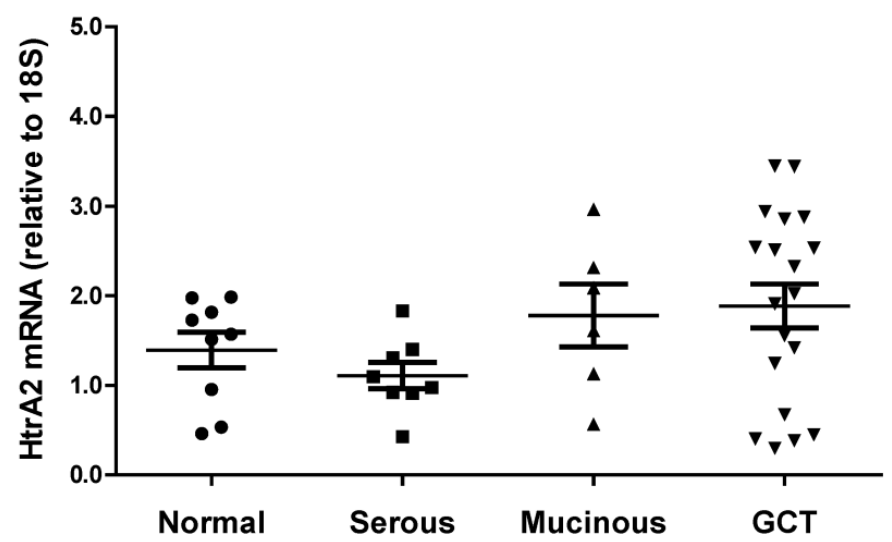

Figure 3. RT-PCR analysis of human HtrA2 expression in normal ovary and different types of ovarian tumors. (A) Representative semi-quantitative RT-PCR results from normal ovary and serous, mucinous and granulosa cell tumor (GCT) ovarian cancers. (B) Densitometric analysis showing relative mRNA levels (corrected for $18 \mathrm{~S}$ ) in normal ovary and ovarian cancer samples. Patient details for normal and cancer groups are summarised in table $\mathrm{I}$. 


\section{A}

Normal
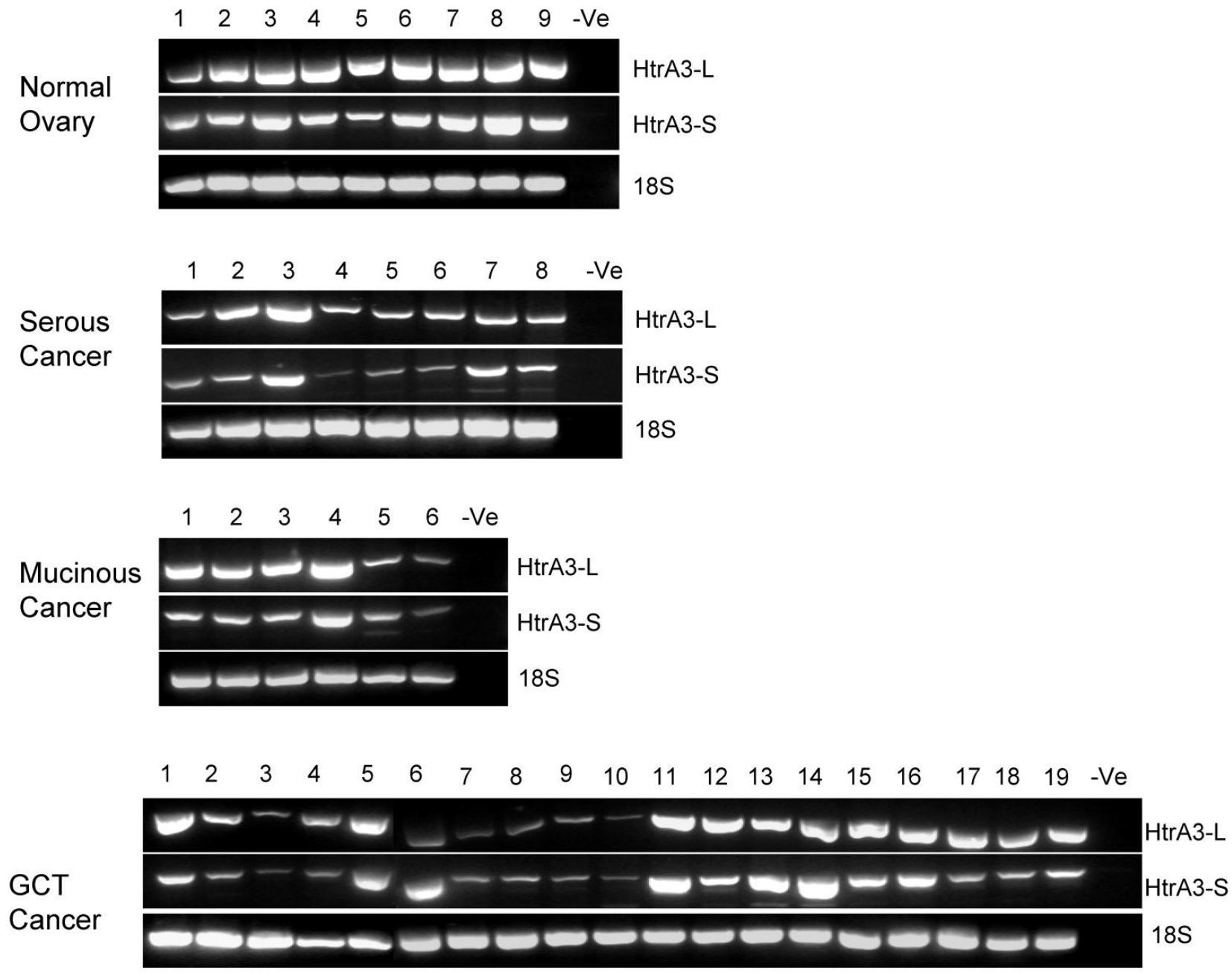

B
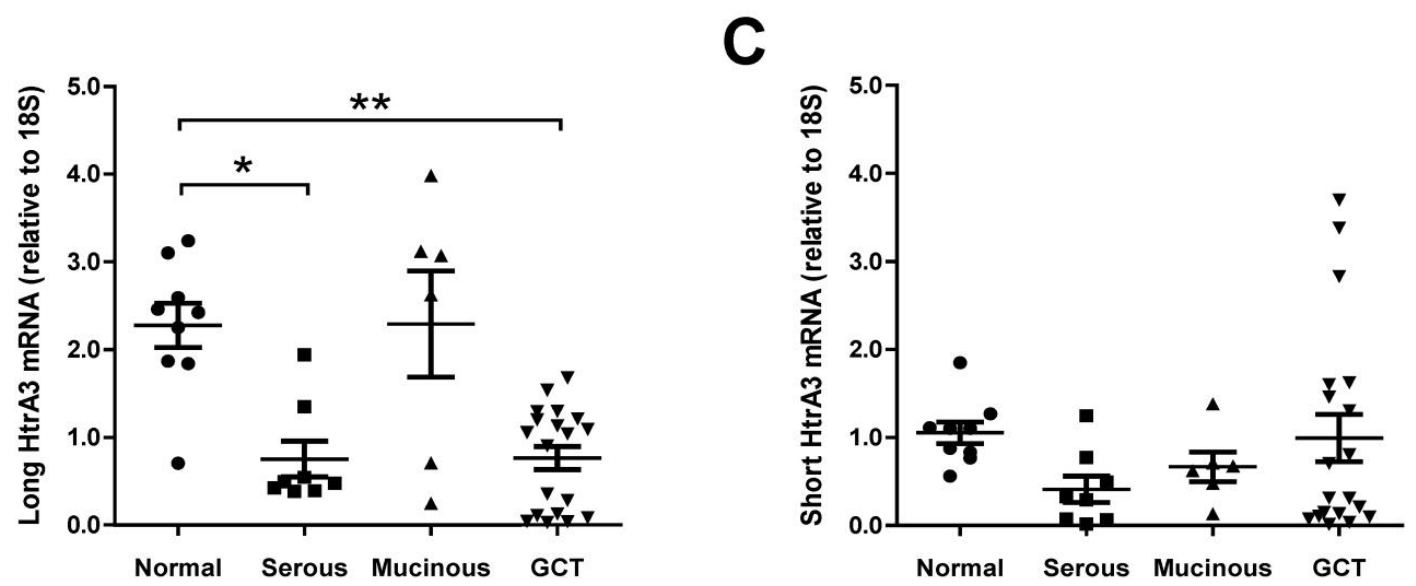

Figure 4. RT-PCR analysis of human HtrA3 (HtrA3-L and HtrA3-S) expression in normal ovary and different types of ovarian tumors. (A) Representative semi-quantitative RT-PCR results from normal ovary and serous, mucinous and granulosa cell tumor (GCT) ovarian cancers. (B \& C) Densitometric analysis showing relative mRNA levels (corrected for $18 \mathrm{~S}$ ) in normal ovary and ovarian cancer samples. Patient details for normal and cancer groups are summarised in table $\mathrm{I}$. $* \mathrm{P}<0.05, * * \mathrm{P}<0.0 \mathrm{I}$. 


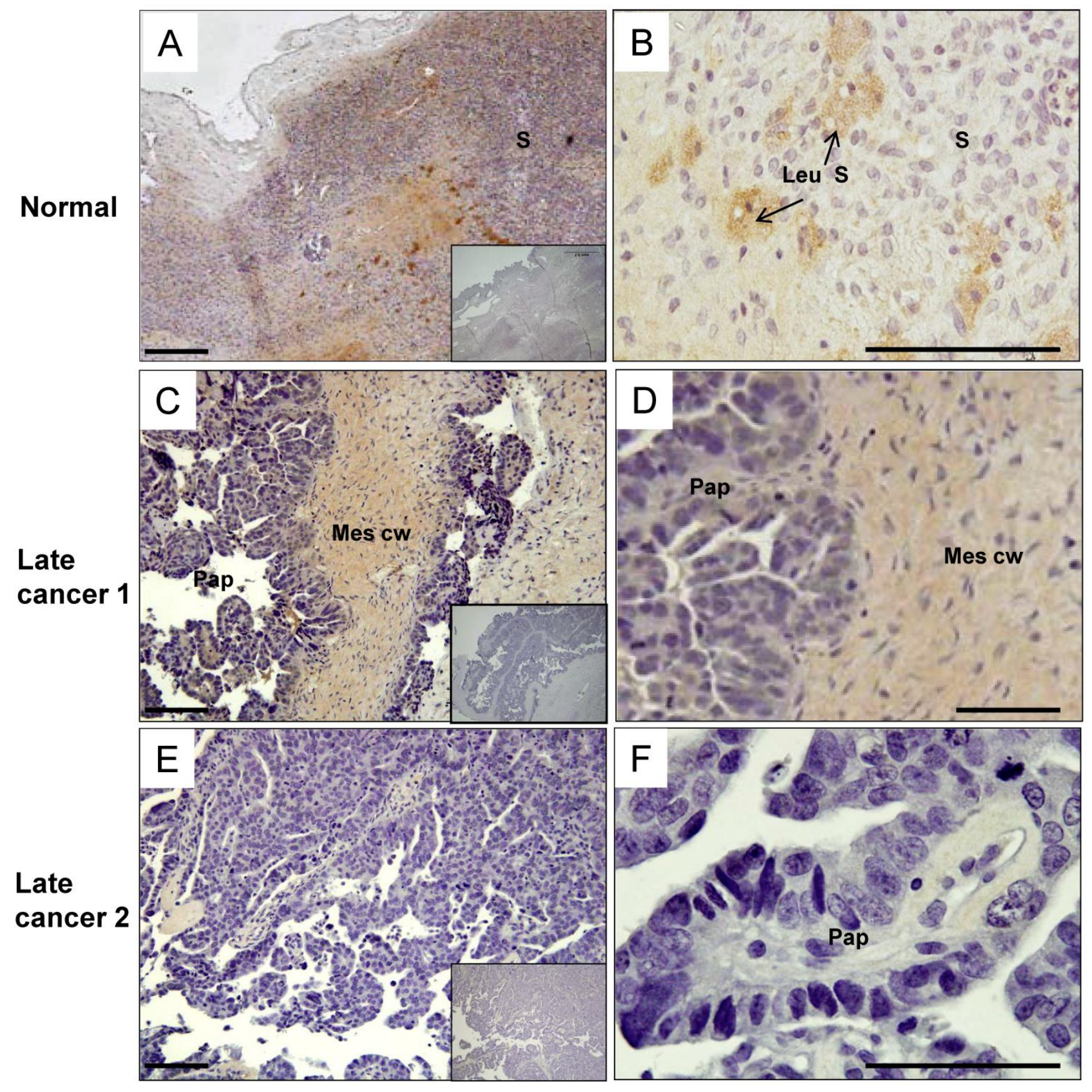

Figure 5. Human HtrA3 in normal and serous ovarian cancer tissues. Representative micrographs of post-menopausal control ovary and two serous (grade 3) cancer tissues immunostained for HtrA3. (A, B) Normal ovary, (C, D, E, F) Serous cancer - grade (G3) from different patients. Right panel images are magnified view. Negative controls (preimmune sheep lgG) are in lower right inserts. Scale bar $=200 \mu \mathrm{m}$; applies to all panels. S - stromal cells; Leu S - lutenizing stromal cells; Mes cw - mesenchymal cell wall; Pap - papillae.

\section{Discussion}

This study describes the comparison of the expression of HtrA serine proteases HtrA1, HtrA2 and HtrA3 (HtrA3-L and HtrA3-S) in various cancer cell lines and in primary ovarian tumors. Our study demonstrates that both HtrA3-L and HtrA3-S are more widely lost than HtrA1 or HtrA2 in various cancer cell lines. In addition, we present evidence that HtrA3-L mRNA is significantly downregulated in primary serous and GCTs compared to normal controls. Our results also confirmed a downregulation of HtrA3 protein in late stage serous carcinoma. These findings provide further evidence that HtrA3-L may play an active role as a tumor suppressor in human GCTs and serous carcinomas. 
Our results are in agreement with the previous studies showing the downregulation of human HtrA3 in ovarian, endometrial and lung cancers. Both HtrA1 and HtrA3 are secreted proteins with similar domain organisation, suggesting they have similar functions. Though previous studies have reported the downregulation of HtrA1 mRNA in different types of ovarian tumors [21,33], our study revealed that the downregulation of HtrA3 is more widespread and extensive. In this study, HtrA1 was not found to be significantly reduced in various cancer cell lines or in primary ovarian tumors compared to normal controls. A previous study by Chien et al [21] has also shown that HtrA3 expression was lost in ovarian cell lines expressing HtrA1. Our study found differential expression for HtrA1 and HtrA3, not only in cancer cell lines but also in primary ovarian tumors. However, no direct correlation was observed between HtrA1 and HtrA3 levels in any of the sample group. The differential expression between HtrA1 and HtrA3 in ovarian cancer cells is intriguing; its significance warrants further investigation.

Both HtrA3-L and HtrA3-S are downregulated in human GCT-derived cell lines, while only HtrA3-L was significantly downregulated in human primary GCT and serous carcinoma. Though levels of HtrA3-S also showed a similar downward pattern in serous carcinoma, it was not significantly different. Higher expression levels of HtrA3-L have been previously reported in rat ovaries and also in primary granulosa cells treated with follicle-stimulating hormone [38]. It is therefore possible that HtrA3 levels are decreased or non-detectable in the GCTs and GCT derived cell lines which cannot undergo luteinization. Since both HtrA3-L and HtrA3-S isoforms are proteolytically active [39], further work needs to resolve the role of $\mathrm{HtrA3}-\mathrm{L}$ in ovarian tumorigenesis.

HtrA3 can bind to TGF- $\beta$ family members and inhibit TGF- $\beta$ signalling, and its proteolytic activity is essential for the inhibition [40]. It has also been shown to regulate the IGF/IGFBP system $[13,41]$ A number of ovarian processes require the action of growth factors including IGF- 1 and TGF- $\beta$ superfamily members [42]. Studies have shown that TGF- $\beta 1$ can act as a tumor suppressor at the early stages of tumorigenesis, when the tumor is still benign, and as a stimulator of tumor progression, invasion and metastasis at the late stages of tumorigenesis [43]. Furthermore, HtrA3 exhibits substrate specificity toward certain extracellular matrix proteoglycans like decorin, biglycan and fibronectin [40], facilitates cell migration and invasion [24, 44], and hence HtrA3 may also modulate the ECM environment of the ovary. It is therefore possible that HtrA3 plays a role in ovarian tumorigenesis by regu- lating the actions and signalling of these growth factor systems in the ovary.

Additional support for $\mathrm{HtrA} 3$ as a putative tumor suppressor came from a study in lung cancer. Beleford et al [19] showed that down-regulation of HtrA3 expression in smoking related lung cancers was associated with the cigarette smoke-induced methylation of HtrA3. As evidence exists showing that HtrA3 can be a predictive factor of clinical response to chemotherapy; a higher response rate was found for patients with lung cancers expressing higher levels of HtrA3 [32]. Similarly, due to epigenetic inactivation of HtrA1, lower levels of HtrA1 have been reported in lymph node melanoma, ovary, lung and breast cancers [21, 25, 27, 45]. A previous study by Chien et al has indicated that HtrA1 expression enhanced sensitivity to cisplatin and paclitaxel, whereas down-regulation attenuated cytotoxicity in ovarian and gastric cancers [46]. A better understanding of the molecular mechanisms involved in ovarian tumor development may help to distinguish between the high- and low-risk patients and improve their clinical management.

Proteases have been implicated in the development and progression of cancer, by degrading ECM and facilitating cell migration and invasion [47]. However, a new concept is emerging demonstrating that proteases can act as tumour-suppressors. Specific serine proteases in the normal breast, prostate and testis are downregulated in cancers and function as tumour suppressors either by a loss of the gene or methylation in the promoter [48, 49]. Our data suggests that HtrA3 may represent another tumor suppressor in this group.

Moreover, the epithelial-to-mesenchymal transition (EMT) which is critical during embryonic development has a parallel role in tumorigenesis and contributes to tumor invasion, metastasis, and acquisition of therapeutic resistance [50-52]. We have previously demonstrated that HtrA3 expression levels are inversely correlated with motility and invasion [24, 44], and acquisition of increased motility is one of the typical features of EMT. Similar to HtrA1 [53], HtrA3 may function as a tumor suppressor by controlling the EMT, and may function in chemotherapeutic responsiveness by mediating DNA damage response pathways.

In summary, we have shown that both HtrA3-L and HtrA3-S are more consistently downregulated than HtrA1 or HtrA2 in various commonly used cancer cell lines. Importantly, HtrA3-L mRNA and protein was significantly downregulated in primary serous and GCTs compared to controls. Collectively this study highlights the potential role of $\mathrm{HtrA} 3$ as a tu- 
mor suppressor. Further studies are needed to enhance our understanding of the role of HtrA3 in normal and malignant cells.

\section{Acknowledgements}

The authors would like to thank Maria Alexiadis for assistance with primary ovarian cancer RNA extraction and RT preparation.

\section{Grant/Funding support}

This project was supported by NHMRC Research Fellowships GNT0494808 (SRF to GN), GNT01002559 (SPRF to PJF), Program Grant GNT0494802, GNT1013533 (CDF to CH), the Victorian Government's Operational Infrastructure Support Program, and the Ovarian Cancer Research Foundation (JR and ANS). The data submitted were audited (PHI Data Audit 12-26).

\section{Competing Interests}

The authors have declared that no competing interest exists.

\section{References}

1. Greenlee RT, Murray T, Bolden S, Wingo PA. Cancer statistics, 2000. CA Cancer J Clin 2000;50: 7-33.

2. Hough CD, Sherman-Baust CA, Pizer ES, Montz FJ, Im DD, Rosenshein NB, Cho KR, Riggins GJ, Morin PJ. Large-scale serial analysis of gene expression reveals genes differentially expressed in ovarian cancer. Cancer Res 2000;60: 6281-7.

3. Brun JL, Feyler A, Chene G, Saurel J, Brun G, Hocke C. Long-term results and prognostic factors in patients with epithelial ovarian cancer. Gynecol Oncol 2000;78: 21-7.

4. Coticchia CM, Yang J, Moses MA. Ovarian cancer biomarkers: current options and future promise. J Natl Compr Canc Netw 2008;6: 795-802.

5. Herzog TJ. Recurrent ovarian cancer: how important is it to treat to disease progression? Clin Cancer Res 2004;10: 7439-49.

6. Lipinska B, Zylicz M, Georgopoulos C. The HtrA (DegP) protein, essential for Escherichia coli survival at high temperatures, is an endopeptidase. J Bacteriol 1990;172: 1791-7.

7. Krojer T, Garrido-Franco M, Huber R, Ehrmann M, Clausen T. Crystal structure of DegP (HtrA) reveals a new protease-chaperone machine. Nature 2002;416: 455-9.

8. Spiess C, Beil A, Ehrmann M. A temperature-dependent switch from chaperone to protease in a widely conserved heat shock protein. Cell 1999;97: 339-47.

9. Hu SI, Carozza M, Klein M, Nantermet P, Luk D, Crowl RM. Human HtrA, an evolutionarily conserved serine protease identified as a differentially expressed gene product in osteoarthritic cartilage. J Biol Chem 1998;273: 34406-12.

10. Zumbrunn J, Trueb B. Primary structure of a putative serine protease specific for IGF-binding proteins. FEBS Lett 1996;398: 187-92.

11. Faccio L, Fusco C, Chen A, Martinotti S, Bonventre JV, Zervos AS. Characterization of a novel human serine protease that has extensive homology to bacterial heat shock endoprotease HtrA and is regulated by kidney ischemia. J Biol Chem 2000;275: 2581-8.

12. Gray CW, Ward RV, Karran E, Turconi S, Rowles A, Viglienghi D, Southan C, Barton A, Fantom KG, West A, Savopoulos J, Hassan NJ, Clinkenbeard H, Hanning C, Amegadzie B, Davis JB, Dingwall C, Livi GP, Creasy CL. Characterization of human HtrA2, a novel serine protease involved in the mammalian cellular stress response. Eur J Biochem 2000;267: 5699-710.

13. Nie GY, Hampton A, Li Y, Findlay JK, Salamonsen LA. Identification and cloning of two isoforms of human high-temperature requirement factor A3 (HtrA3), characterization of its genomic structure and comparison of its tissue distribution with HtrA1 and HtrA2. Biochem J 2003;371: 39-48.
14. Nie G, Li Y, Hale K, Okada H, Manuelpillai U, Wallace EM, Salamonsen LA. Serine peptidase HTRA3 is closely associated with human placental development and is elevated in pregnancy serum. Biol Reprod 2006;74: 366-74.

15. Inagaki A, Nishizawa $H$, Ota $S$, Suzuki $M$, Inuzuka $H$, Miyamura $H$, Sekiya T, Kurahashi H, Udagawa Y. Upregulation of HtrA4 in the placentas of patients with severe pre-eclampsia. Placenta 2012;33: 919-26.

16. Wang LJ, Cheong ML, Lee YS, Lee MT, Chen H. High-temperature requirement protein A4 (HtrA4) suppresses the fusogenic activity of syncytin-1 and promotes trophoblast invasion. Mol Cell Biol 2012;32: 3707-17.

17. Oka C, Tsujimoto R, Kajikawa M, Koshiba-Takeuchi K, Ina J, Yano M, Tsuchiya A, Ueta Y, Soma A, Kanda H, Matsumoto M, Kawaichi M. HtrA1 serine protease inhibits signaling mediated by Tgfbeta family proteins. Development 2004;131: 1041-53.

18. Clausen T, Southan C, Ehrmann M. The HtrA family of proteases: implications for protein composition and cell fate. Mol Cell 2002;10: 443-55.

19. Beleford D, Liu Z, Rattan R, Quagliuolo L, Boccellino M, Baldi A, Maguire J, Staub J, Molina J, Shridhar V. Methylation induced gene silencing of HtrA3 in smoking-related lung cancer. Clin Cancer Res 2010;16: 398-409.

20. Bowden MA, Di Nezza-Cossens LA, Jobling T, Salamonsen LA, Nie G. Serine proteases HTRA1 and HTRA3 are down-regulated with increasing grades of human endometrial cancer. Gynecol Oncol 2006;103: 253-60.

21. Chien J, Staub J, Hu SI, Erickson-Johnson MR, Couch FJ, Smith DI, Crowl RM, Kaufmann SH, Shridhar V. A candidate tumor suppressor HtrA1 is downregulated in ovarian cancer. Oncogene 2004;23: 1636-44.

22. Ajayi F, Kongoasa N, Gaffey T, Asmann YW, Watson WJ, Baldi A, Lala P, Shridhar V, Brost B, Chien J. Elevated expression of serine protease HtrA1 in preeclampsia and its role in trophoblast cell migration and invasion. Am J Obstet Gynecol 2008;199: 557.e1-10.

23. Chien J, Campioni M, Shridhar V, Baldi A. HtrA serine proteases as potential therapeutic targets in cancer. Curr Cancer Drug Targets 2009;9: 451-68.

24. Singh H, Makino SI, Endo Y, Nie G. Inhibition of HTRA3 stimulates trophoblast invasion during human placental development. Placenta 2010;31: 1085-92.

25. Baldi A, De Luca A, Morini M, Battista T, Felsani A, Baldi F, Catricala C, Amantea A, Noonan DM, Albini A, Natali PG, Lombardi D, Paggi MG. The HtrA1 serine protease is down-regulated during human melanoma progression and represses growth of metastatic melanoma cells. Oncogene 2002;21: 6684-8.

26. Shridhar V, Sen A, Chien J, Staub J, Avula R, Kovats S, Lee J, Lillie J, Smith DI. Identification of underexpressed genes in early- and late-stage primary ovarian tumors by suppression subtraction hybridization. Cancer Res 2002;62: 262-70.

27. Loss LA, Sadanandam A, Durinck S, Nautiyal S, Flaucher D, Carlton VE, Moorhead M, Lu Y, Gray JW, Faham M, Spellman P, Parvin B. Prediction of epigenetically regulated genes in breast cancer cell lines. BMC Bioinformatics 2010;11: 305 .

28. Srinivasula SM, Gupta S, Datta P, Zhang Z, Hegde R, Cheong N, Fernandes-Alnemri T, Alnemri ES. Inhibitor of apoptosis proteins are substrates for the mitochondrial serine protease Omi/HtrA2. J Biol Chem 2003;278: 31469-72

29. Trencia A, Fiory F, Maitan MA, Vito P, Barbagallo AP, Perfetti A, Miele C, Ungaro P, Oriente F, Cilenti L, Zervos AS, Formisano P, Beguinot F. Omi/HtrA2 promotes cell death by binding and degrading the anti-apoptotic protein ped/pea-15. J Biol Chem 2004;279: 46566-72.

30. Yang QH, Church-Hajduk R, Ren J, Newton ML, Du C. Omi/HtrA2 catalytic cleavage of inhibitor of apoptosis (IAP) irreversibly inactivates IAPs and facilitates caspase activity in apoptosis. Genes Dev 2003;17: 1487-96.

31. Nie GY, Li Y, Minoura H, Batten L, Ooi GT, Findlay JK, Salamonsen LA. A novel serine protease of the mammalian HtrA family is up-regulated in mouse uterus coinciding with placentation. Mol Hum Reprod 2003;9: 279-90.

32. Beleford D, Rattan R, Chien J, Shridhar V. High temperature requirement A3 (HtrA3) promotes etoposide- and cisplatin-induced cytotoxicity in lung cancer cell lines. J Biol Chem 2010;285: 12011-27.

33. Narkiewicz J, Klasa-Mazurkiewicz D, Zurawa-Janicka D, Skorko-Glonek J, Emerich J, Lipinska B. Changes in mRNA and protein levels of human HtrA1, HtrA2 and HtrA3 in ovarian cancer. Clin Biochem 2008;41: 561-9.

34. Fuller PJ, Alexiadis M, Jobling T, McNeilage J. Seladin-1/DHCR24 expression in normal ovary, ovarian epithelial and granulosa tumours. Clin Endocrinol (Oxf) 2005;63: 111-5. 
35. Jamieson S, Alexiadis M, Fuller PJ. Expression status and mutational analysis of the ras and B-raf genes in ovarian granulosa cell and epithelial tumors. Gynecol Oncol 2004;95: 603-9.

36. Jamieson S, Butzow R, Andersson N, Alexiadis M, Unkila-Kallio L, Heikinheimo M, Fuller PJ, Anttonen M. The FOXL2 C134W mutation is characteristic of adult granulosa cell tumors of the ovary. Mod Pathol 2010;23: 1477-85.

37. Fuller PJ, Chu S, Jobling T, Mamers P, Healy DL, Burger HG. Inhibin subunit gene expression in ovarian cancer. Gynecol Oncol 1999;73: 273-9.

38. Bowden MA, Drummond AE, Fuller PJ, Salamonsen LA, Findlay JK, Nie G. High-temperature requirement factor A3 (Htra3): a novel serine protease and its potential role in ovarian function and ovarian cancers. Mol Cell Endocrinol 2010;327: 13-8.

39. Singh H, Makino S, Endo Y, Li Y, Stephens AN, Nie G. Application of the wheat-germ cell-free translation system to produce high temperature requirement A3 (HtrA3) proteases. Biotechniques 2012;52: 23-8.

40. Tocharus J, Tsuchiya A, Kajikawa M, Ueta Y, Oka C, Kawaichi M. Developmentally regulated expression of mouse HtrA3 and its role as an inhibitor of TGF-beta signaling. Dev Growth Differ 2004;46: 257-74.

41. Hou J, Clemmons DR, Smeekens S. Expression and characterization of a serine protease that preferentially cleaves insulin-like growth factor binding protein-5. J Cell Biochem 2005;94: 470-84.

42. Richards JS, Russell DL, Ochsner S, Hsieh M, Doyle KH, Falender AE, Lo YK, Sharma SC. Novel signaling pathways that control ovarian follicular development, ovulation, and luteinization. Recent Prog Horm Res 2002;57: 195-220.

43. Akhurst RJ, Derynck R. TGF-beta signaling in cancer--a double-edged sword. Trends Cell Biol 2001;11: S44-51.

44. Singh H, Endo Y, Nie G. Decidual HtrA3 negatively regulates trophoblast invasion during human placentation. Hum Reprod 2011;26: 748-57.

45. Esposito V, Campioni M, De Luca A, Spugnini EP, Baldi F, Cassandro R, Mancini A, Vincenzi B, Groeger A, Caputi M, Baldi A. Analysis of HtrA1 serine protease expression in human lung cancer. Anticancer Res 2006;26: 3455-9.

46. Chien J, Aletti G, Baldi A, Catalano V, Muretto P, Keeney GL, Kalli KR, Staub J, Ehrmann M, Cliby WA, Lee YK, Bible KC, Hartmann LC, Kaufmann SH, Shridhar V. Serine protease HtrA1 modulates chemotherapy-induced cytotoxicity. J Clin Invest 2006;116: 1994-2004.

47. Turk B. Targeting proteases: successes, failures and future prospects. Nat Rev Drug Discov 2006;5: 785-99.

48. Goyal J, Smith KM, Cowan JM, Wazer DE, Lee SW, Band V. The role for NES1 serine protease as a novel tumor suppressor. Cancer Res 1998;58: 4782-6.

49. Lopez-Otin C, Matrisian LM. Emerging roles of proteases in tumour suppression. Nat Rev Cancer 2007;7: 800-8.

50. Dvorak HF. Tumors: wounds that do not heal. Similarities between tumor stroma generation and wound healing. N Engl J Med 1986;315: 1650-9.

51. Thiery JP. Epithelial-mesenchymal transitions in development and pathologies. Curr Opin Cell Biol 2003;15: 740-6.

52. Polyak K, Weinberg RA. Transitions between epithelial and mesenchymal states: acquisition of malignant and stem cell traits. Nat Rev Cancer 2009;9: 265-73.

53. Wang N, Eckert KA, Zomorrodi AR, Xin P, Pan W, Shearer DA, Weisz J, Maranus CD, Clawson GA. Down-regulation of HtrA1 activates the epithelial-mesenchymal transition and ATM DNA damage response pathways. PLoS One 2012;7: e39446. 